\title{
Metastatic Renal Cell Carcinoma with Metabolic Syndrome- A Case Report
}

\author{
KEMPER KELLY, CARRIE COCKLIN
}

\begin{abstract}
Renal cell carcinoma (RCC) affects patients by proliferating in the renal tubules, resulting in renal failure and concomitant urinalysis findings of blood, protein, casts, and abnormal cells in the urine. If untreated, it can spread to the lymph nodes, liver, and lungs. There is currently no proven tumor marker for RCC. The clinical case reported here describes the clinical laboratory findings in a patient with 2 common co-morbidities (metabolic syndrome and alcoholism), who was found to have metastatic renal cell carcinoma at autopsy. Understanding the clinical chemistry of metastatic carcinoma in the presence of common co-morbidities is important for earlier diagnosis and treatment of patients who are most likely to develop these conditions.
\end{abstract}

INDEX TERMS: RCC, renal cancer, CAIX, carbonic anhydrase

ABBREVIATIONS: ALP $=$ Alkaline phosphatase, Hct $=$ Hematocrit, AST $=$ Aspartate aminotransferase, $\mathrm{MCV}=$ Mean corpuscular volume, $\mathrm{ALT}=$ Alanine transaminase, $\mathrm{MCHC}=$ Mean corpuscular hemoglobin concentration, $\mathrm{BUN}=$ Blood urea nitrogen, $\mathrm{RDW}=$ Red blood cell distribution width, GFR= Glomerular filtration rate, PLT $=$ Platelet, $\mathrm{WBC}=$ White Blood Cells, INR= International normalized ratio, $\mathrm{aPTT}=$ activated Partial thromboplastin time, GGT $=$ Gamma-glutamyl transferase.

Clin Lab Sci 2010;23(3):141

Kemper Kelly, MT(ASCP), 88 th DTS/SGQC, WrightPatterson AFB, OH 45433.

Carrie Cocklin, M.D., Institution: Indiana University, Purdue University at Indianapolis, IN 46202
Address for Correspondence: Kemper Kelly, $M T(A S C P), 88^{\text {th }}$ DTS/SGQC, 4881 Sugar Maple Dr, Wright-Patterson AFB, OH 45433, kemper.kelly@ wpafb.af.mil, 937-257-9375, (fax)937-257-9342.

\section{Patient History}

An obese 66-year-old male presented to an outpatient center with generalized weakness, fatigue, thirty-five pound weight loss, shortness of breath, lower extremity edema, and oliguria. The patient had a medical history of coronary artery disease (status post coronary artery bypass graft), hypertension, hyperlipidemia, obesity, malnutrition, alcoholism, chronic renal disease and RCC. Two weeks later, the patient was transferred to a large medical center presenting with acute and chronic renal failure, lethargy, edema in both legs, and elevated liver function tests. While in the hospital, the patient experienced respiratory failure, right lower extremity cellulitis, sepsis, multiorgan failure, disseminated intravascular coagulation, and several hypotensive and tachycardic episodes. One week later, the patient was not responding to treatment. His family stopped supportive therapy, and he died later that day. An autopsy revealed a tumor in the right kidney, which extended into the perinephric fat with metastases to the liver and lungs. The heart revealed fibrosis from an earlier myocardial infarction.

\section{Overview on Renal Cell Carcinoma}

Renal cell carcinoma is responsible for 3\% of all cancers in adults and $85 \%$ of all malignant kidney tumors. ${ }^{1}$ It will initially grow in the tubules of the nephrons. ${ }^{1,2}$ Males are at a higher risk for developing RCC. ${ }^{2}$ Other risk factors include smoking, obesity, high blood pressure, family history of RCC, or genetic problems such as von Hippel-Lindau Disease. ${ }^{1,2,3}$ Typical symptoms of RCC are hema- 


\section{CLINICAL PRACTICE}

turia, abdominal or flank pain, anemia, a lump in the abdominal area, reduction in appetite, and rapid weight loss. ${ }^{1,2}$

Prognosis for patients with RCC is good if the tumor is localized in the kidney, but spreading to the lymph nodes carries a poor prognosis. ${ }^{2}$ If the RCC is completely untreated and becomes metastatic, one year survival is only $12 \%{ }^{4}$ Although the spread of RCC to the lymph nodes and liver is associated with a lower survival rate, RCC metastasis to the lungs have little, if any affect, on survival. ${ }^{4}$ Other factors associated with a much lower survival rate are a $\mathrm{Hgb}$ $<11 \mathrm{~g} / \mathrm{dL}$, neutrophil count $\geq 6500 / \mathrm{uL}$, and $\mathrm{LDH}$ $\geq 220$. $^{4}$

This patient had a history of obesity, hypertension, and malnutrition, and alcoholism. He presented with symptoms of anemia and a thirty-five pound weight loss. The patient had hematuria and decreased hemoglobin. The post-mortem examination revealed RCC extending into the perinephric fat and metastases to lymph nodes, liver, and lungs.

\section{RCC effects on the kidney}

The GFR is a measure of the kidney's ability to filter substances from the blood and is also a rough estimate of the amount of functioning nephrons. ${ }^{6}$ RCC is initially formed in the tubules (nephrons) of a kidney. ${ }^{1}$ Therefore, over time, the tumor's growth will crowd out and damage more nephrons. During renal failure, the serum BUN and creatinine will increase as the GFR decreases. The removal of BUN and creatinine from the blood is slowed down as the GFR decreases, leaving these waste products to accumulate in the blood. ${ }^{6}$ Increased nitrogen in the blood (uremia) can present with symptoms of nausea, lethargy, and vomiting. ${ }^{6}$ Hematuria is often seen in conditions causing renal injury and is a common symptom of renal tumors. ${ }^{1,2,7}$ Many rapid urine screening tests measure the amount of albumin in the urine as a way to determine if there is protein present. ${ }^{7}$ A normal blood albumin level is necessary to maintain the correct oncotic pressure and prevent edema. ${ }^{6}$ In addition to carcinoma damaging nearby nephrons, proteinuria also damages the glomeruli. ${ }^{6}$ Renal casts and glycoproteins can damage the kidneys if many are present in the urine. ${ }^{6,7}$ These casts are composed of uromodulin (Tamm-Horsfall protein) and are produced in the ascending loop of Henle and the distal convoluted tubules by renal tubular epithelial cells. ${ }^{6,7}$ Casts can take the shape of the tubules as they get excreted in the urine. ${ }^{7}$ Healthy people have few, if any, casts present. ${ }^{7}$ Increased numbers of hyaline casts are seen in patients with renal problems or congestive heart failure. ${ }^{7}$ Cast formation is enhanced by an acidic $\mathrm{pH}$, which the patient had as shown in Table $1 .^{7}$

Table 1: Urinalysis (Hospital Day 1)

\begin{tabular}{lll}
\hline & Patient & Reference \\
Color & Yellow & \\
Clarity & Slt. Cloudy & \\
Sp Gravity & 1.013 & $1.003-1.030$ \\
pH & 5.00 & $5.00-8.00$ \\
Protein & 30.00 & Negative \\
Glucose & Normal & Negative \\
Ketones & Negative & Negative \\
Bilirubin & Negative & Negative \\
Nitrate & Negative & Negative \\
Urobilinogen & $2.0 \mathrm{mg} / \mathrm{dL}$ & $<1.0 \mathrm{mg} / \mathrm{dL}$ \\
Leukocyte Esterase & Negative & Negative \\
RBC & 7 RBCs/ $\mu \mathrm{L}$ & $0-2 \mathrm{RBCs} / \mu \mathrm{L}$ \\
Hgb & $20 \mathrm{mg} / \mathrm{dL}$ & Negative \\
Bacteria & Occasional & Negative \\
Mucus & Rare & Negative \\
Casts & $10-20 \mathrm{Hyaline} / \mathrm{lpf}$ & $0-2 / \mathrm{lpf}$ \\
& & \\
RBC= Red Blood Cells & \\
Hgb= Hemoglobin & & \\
\hline
\end{tabular}

The patient's renal panel, shown in Table 2, indicates that his GFR was below normal. His abnormal GFR led to reduced urine output (oliguria) when he was admitted. ${ }^{6}$ The edema in his lower extremities was due to decreased albumin in the blood and increased excretion through the urine. The patient was described as lethargic (a symptom of severe anemia) when he was transferred to the larger medical facility. Table 2 shows that his serum BUN was increased and that the creatinine was twice the upper limit of normal. Blood and protein were present in the urine (Table 1) and that many hyaline casts were seen per low power field. This patient had a clinical history of coronary artery disease and chronic renal failure, 


\section{CLINICAL PRACTICE}

which can explain the presence of increased hyaline casts.

Table 2: Complete Metabolic Panel, Complete Blood Count and Coagulation (Hospital Day 5)

\begin{tabular}{|c|c|c|}
\hline & $\underline{\text { Patient }}$ & $\underline{\text { Reference }}$ \\
\hline Albumin & $2.2 \mathrm{~g} / \mathrm{dL}$ & $3.5-5.0 \mathrm{~g} / \mathrm{dL}$ \\
\hline Total Protein & $5.3 \mathrm{~g} / \mathrm{dL}$ & $6.7-8.6 \mathrm{~g} / \mathrm{dL}$ \\
\hline Direct Bilirubin & $3.2 \mathrm{mg} / \mathrm{dL}$ & $0-0.5 \mathrm{mg} / \mathrm{dL}$ \\
\hline Total Bilirubin & $5.9 \mathrm{mg} / \mathrm{dL}$ & $0-1.0 \mathrm{mg} / \mathrm{dL}$ \\
\hline ALP & 205 IU/L & $25-125 \mathrm{IU} / \mathrm{L}$ \\
\hline AST & $471 \mathrm{IU} / \mathrm{L}$ & 15-41 IU/L \\
\hline ALT & 137 IU/L & $0-45 \mathrm{IU} / \mathrm{L}$ \\
\hline Serum Total $\mathrm{CO}_{2}$ & $21 \mathrm{mmol} / \mathrm{L}$ & $22-29 \mathrm{mmol} / \mathrm{L}$ \\
\hline Serum BUN & $26 \mathrm{mg} / \mathrm{dL}$ & $5-20 \mathrm{mg} / \mathrm{dL}$ \\
\hline Serum Creatinine & $2.4 \mathrm{mg} / \mathrm{dL}$ & $0.8-1.4 \mathrm{~g} / \mathrm{dL}$ \\
\hline GFR & $29 \mathrm{~mL} / \mathrm{min} / 1.73 \mathrm{~m} 2$ & $30-59$ \\
\hline \multicolumn{3}{|l|}{$\mathrm{mL} / \mathrm{min} / 1.73 \mathrm{~m} 2$} \\
\hline Serum Glucose & $109 \mathrm{mg} / \mathrm{dL}$ & $70-109 \mathrm{mg} / \mathrm{dL}$ \\
\hline Serum $\mathrm{Ca}^{2+}$ & $9.0 \mathrm{mg} / \mathrm{dL}$ & $8.5-10.5 \mathrm{mg} / \mathrm{dL}$ \\
\hline Serum $\mathrm{PO}_{4}^{3-}$ & $4.3 \mathrm{mg} / \mathrm{dL}$ & $2.5-4.9 \mathrm{mg} / \mathrm{dL}$ \\
\hline Serum Albumin & $2.4 \mathrm{~g} / \mathrm{L}$ & $3.5-5 \mathrm{~g} / \mathrm{L}$ \\
\hline WBC & $11500 / \mathrm{uL}$ & $4500-11500 / \mu \mathrm{L}$ \\
\hline $\mathrm{RBC}$ & 4.41 million/uL & 4.6-60 million $/ \mu \mathrm{L}$ \\
\hline $\mathrm{Hgb}$ & $9.8 \mathrm{~g} / \mathrm{dL}$ & $14-18 \mathrm{~g} / \mathrm{dL}$ \\
\hline Hct & $30.8 \%$ & $40-54 \%$ \\
\hline $\mathrm{MCV}$ & $70 \mu^{3}$ & $80-94 \mu^{3}$ \\
\hline $\mathrm{MCHC}$ & $31.8 \mathrm{~g} / \mathrm{dL}$ & $32-36 \mathrm{~g} / \mathrm{dL}$ \\
\hline RDW & $30 \%$ & $11.5-14.5 \%$ \\
\hline PLT & $73 \mathrm{~K} / \mathrm{uL}$ & $150 \mathrm{~K}-450 \mathrm{~K} / \mu \mathrm{L}$ \\
\hline Fibrinogen & $415 \mathrm{mg} / \mathrm{dL}$ & $192-389 \mathrm{mg} / \mathrm{dL}$ \\
\hline INR & 2.99 & $0.9-1.1$ \\
\hline aPTT & $132 \mathrm{sec}$ & $22-36 \mathrm{sec}$ \\
\hline
\end{tabular}

\section{RCC effects on the liver}

Liver function tests were assessed as shown in Table 2. The ALP, AST, and ALT were all increased, (Table 2) and the serum albumin and protein levels were reduced. The liver is responsible for protein metabolism; less protein will be made if its function is impaired. ${ }^{8}$ Table 2 also shows that his total and direct serum bilirubin were both elevated. Albumin transports unconjugated bilirubin to the liver where it is metabolized using glucuronic acid into direct bilirubin. A portion of bilirubin is converted to urobilinogen in the intestine and eventually gets excreted into the urine and feces.' However, the reduction of albumin in the serum, as shown in Tables 2 and 3, explains why the total bilirubin is increased. The liver, despite the effects of alcohol and tumors, was still able to produce glucuronic acid, since the direct bilirubin was also increased as well as the urinary urobilinogen (shown on Table 1). ${ }^{7,9}$ However, if another complete urinalysis was done, the urine would have probably been positive for bilirubin since the serum direct bilirubin was increased. The AST:ALT ratio was greater than two, which is consistent with alcoholic liver disease. ${ }^{8}$ Finally, the patient's autopsy showed that the "liver was almost completely replaced by metastatic nodules and associated necrosis.”

Table 3: Blood Gas and Liver Transplant Panel (Hospital Day 5)

\begin{tabular}{|c|c|c|}
\hline & Patient & Reference \\
\hline $\mathrm{HCO}_{3}^{-}$ & $17.3 \mathrm{mmol} / \mathrm{L}$ & $22-29 \mathrm{mmol} / \mathrm{L}$ \\
\hline $\mathrm{pH}$ & 7.35 & $7.35-7.45$ \\
\hline $\mathrm{pO}_{2}$ & $67 \mathrm{mmHg}$ & $80-110 \mathrm{mmHg}$ \\
\hline $\mathrm{O}_{2}$ Saturated & $92 \%$ & $95-98 \%$ \\
\hline Base Excess & $-7 \mathrm{mmol} / \mathrm{L}$ & -2 to $2 \mathrm{mmol} / \mathrm{L}$ \\
\hline Lactate Assay & $8.7 \mathrm{mmol} / \mathrm{L}$ & $0.5-1.6 \mathrm{mmol} / \mathrm{L}$ \\
\hline $\mathrm{CO}_{2}$ Total & $18 \mathrm{mmol} / \mathrm{L}$ & $22-29 \mathrm{mmol} / \mathrm{L}$ \\
\hline BUN & $47 \mathrm{mg} / \mathrm{dL}$ & $5-20 \mathrm{mg} / \mathrm{dL}$ \\
\hline Creatinine & $3.4 \mathrm{mg} / \mathrm{dL}$ & $0.8-1.4 \mathrm{mg} / \mathrm{dL}$ \\
\hline GFR & $19 \mathrm{~mL} / \mathrm{min} / 1.73 \mathrm{~m} 2$ & $30-59 \mathrm{~mL} / \mathrm{min} / 1.73 \mathrm{~m} 2$ \\
\hline GGT & $174 \mathrm{IU} / \mathrm{L}$ & 15-73 IU/L \\
\hline $\mathrm{PO}_{4}^{3-}$ & $6.3 \mathrm{mg} / \mathrm{dL}$ & $2.5-4.9 \mathrm{mg} / \mathrm{dL}$ \\
\hline
\end{tabular}

Table 2 also shows the results of the patient's complete blood count. The "Rule of Three" is not followed regarding the Hgb's relation to the RBC count. The MCV and MCHC were reduced, indicating microcytic/hypochromic anemia. ${ }^{10}$ The patient's renal function was impaired by the renal carcinoma and chronic renal failure, hence there was impaired renal production of erythropoietin, which is needed to produce red blood cells. The RDW was above the normal level, indicating that the patient's red blood cell size varied widely, (anisocytosis). ${ }^{10}$ The patient's symptoms of generalized weakness, fatigue, and shortness of breath were all typical symptoms of a severely anemic patient. ${ }^{10,11}$

While being treated, the patient had an episode of DIC. During DIC, the PT and APTT will increase, while the platelets and fibrinogen will decrease. ${ }^{12}$ The patient's PT, APTT, and platelets match the findings of typical DIC, as shown on Table 2. The increased PT and APTT, as well as the thrombocytopenia, are 


\section{CLINICAL PRACTICE}

secondary to liver disease which was partially secondary to the spreading renal carcinoma.,12 Thrombocytopenia is also secondary to chronic renal failture. ${ }^{12}$ However, in DIC, the fibrinogen level should be decreased. The patient's fibrinogen assay was increased which is another indicator of liver damage. ${ }^{12}$

\section{RCC effects on the lungs and acid/base state}

The patient's autopsy report stated that the lungs contained small white nodules, as a result of the RCC spreading through the lymphatics. It is possible the patient's saturated oxygen percentage and $\mathrm{pO}_{2}$ was reduced, due to an impaired ability to take in air. This would also explain the patient's episodes of respiratory failure. However, the patient did not appear to have any problems exhaling carbon dioxide. The renal tumor was impairing the kidney's ability to produce bicarbonate, a blood buffer. ${ }^{13}$ Table 3 showed the reduced bicarbonate and reduced base excess, which contributed to his reduction in blood $\mathrm{pH}$, causing a metabolic acidosis. ${ }^{13}$ The patient tried to compensate for this reduction in $\mathrm{pH}$ by lowering the $\mathrm{pCO}_{2}$ in an attempt to increase the $\mathrm{pH}$ to a safe normal level; this can be done by breathing more rapidly. ${ }^{13}$ The patient had several tachycardic episodes while admitted. The patient had an increased lactate assay that was almost four times the upper limit of normal. This is explained by the impaired oxygen intake, due to the renal tumors spreading to the lungs, as well as his anemia. ${ }^{13}$ In the absence of oxygen, the body metabolizes glucose into lactic acid as a waste product which can cause the patient to go into a lactic acidosis. ${ }^{13}$ Lactic acidosis and renal failure can cause the serum phosphate to increase as seen in Table $3 .{ }^{14}$

\section{Treatment for Renal Cell Carcinoma}

There are several available treatments for renal cell carcinoma. Radiation therapy can be used as long as the tumor has not metastasized to other parts of the body. ${ }^{1}$ Metastatic tumors are resistant to radiation therapy. ${ }^{1,2}$ Nephrectomy can also be used if the patient is in good health for surgery and if the other kidney is free of tumors. ${ }^{1,2}$ Chemotherapy can also be used to treat localized and metastatic RCC. ${ }^{2}$ Current treatments, such as interferon alpha and interleukin-2 work by blocking blood supply to the tumors. ${ }^{2,15}$ Side effects of interferon alpha are fever, chills, and similar flu-like symptoms. ${ }^{16}$ A newer drug, Sunitinib, acts by inhibiting blood supply to the tumors by blocking blood vessel growth. ${ }^{16}$ This experimental drug, now in Phase III trials, may halt the progression of RCC metastasis in patients, longer than interferon alpha. ${ }^{16}$ However, Sunitinib is more likely to cause severe episodes of leukopenia and thrombocytopenia. ${ }^{16}$

Several tumor markers are being studies to achieve earlier diagnosis of RCC. A potential tumor marker for RCC is a screen for serum carbonic anhydrase IX (CAIX). ${ }^{5}$ One study suggests that a low amount of CAIX in the serum of a RCC patient is not only associated with a poor prognosis, but that these patients will not respond well to cytokine therapy such as Interleukin 2. ${ }^{5}$ Since CAIX is a cell surface molecule, it may be possible to make an antibody against it or develop drugs that have fewer side effects than current treatments. ${ }^{5}$

\section{Summary}

The clinical chemistry of renal cell carcinoma in the presence of the common co-morbidities afflicting the patient population most at risk is reported here. Renal cell carcinoma (RCC) initially starts in the renal tubules of the nephrons. It will cause renal failure evidenced on a urinalysis by the presence of blood, protein, and casts in the urine. It may be difficult to diagnose because the patient may only complain of feeling weak and tired. It is critical that RCC is diagnosed before it spreads to other body sites, since the mortality then becomes much higher. Several tumor markers for RCC are being studied. Carbonic anhydrase IX is a potential tumor marker that shows some promise for earlier detection of RCC. Current treatments include radiation therapy, nephrectomy, and chemotherapy using interleukin 2 and interferon alpha. Newer drugs might be more effective in treatment but the side effects may be unsuitable for use. 


\section{CLINICAL PRACTICE}

\section{REFERENCES}

1. National Cancer Institute. "Renal cell cancer treatment," Available at: http://www.cancer.gov/cancertopics/pdq/treatment/renalcell/patient. Accessed April 20, 2008.

2. MedlinePlus Medical Encyclopedia. "Renal cell carcinoma," Available at: http://www.nlm.nih.gov/medlineplus/ency/ article/000516.htm Accessed April 11, 2008.

3. Linehan WM, Zbar B. Focus on kidney cancer. Cancer Cell 2004;6(3):223-8

4. Atzpodien J , Royston P, Wandert T, Reitz M, DGCIN German Cooperative Renal Carcinoma ChemoImmunotherapy Trials Group. Metastatic renal carcinoma comprehensive prognostic system. British Journal of Cancer 2003;88:348-53

5. Bui MHT, Seligson D, Han K, Pantuck AJ, Dorey FJ, et al. Carbonic anhydrase IX is an independent predictor of survival in advanced renal clear cell carcinoma: implications for prognosis and therapy. Clinical Cancer Research 2003;9: 802-11

6. Newman DJ, Price CP: Renal function. IN Brutis CA, Ashwood ER, Border BG, editors: Tietz fundamentals of clinical chemistry. Saunders; $5^{\text {th }}$ ed(January 15, 2001): 698722

7. Brunzel NA. Fundamentals of urine and body fluid analysis, 2nd ed. Philadelphia: W.B. Saunders, 2004: 133, 99

8. Tolman KG, Rej R: Liver function. IN Brutis CA, Ashwood ER, Border BG, editors: Tietz fundamentals of clinical chemistry. Saunders; 5 edition (January 15, 2001): 747-70

9. Nuttall KL, Klee GG: Analytes of hemoglobin metabolismporphyrins, iron, and bilirubin. IN Brutis CA, Ashwood ER,
Border BG, editors: Tietz fundamentals of clinical chemistry. Saunders; 5 edition (January 15, 2001): 584-607

10. Bell A: Anemias: RBC morphology and approach to diagnosis. IN Rodak BF: Hematology clinical principles and applications. Philadelphia: Saunders $2^{\text {nd }}$ ed 2002: 199-210

11. National Heart Lung and Blood Institute. "Anemia, Signs and Symptoms," Available at: http://www.nhlbi.nih.gov/ health/dci/Diseases/anemia/anemia_signsandsymptoms.html . Accessed 19 April, 2008.

12. Fritsma GA: Hemorrhagic coagulation disorders \& Thrombosis Risk Testing. IN Rodak BF: Hematology clinical principles and applications. Philadelphia: Saunders $2^{\text {nd }}$ ed 2002: 627-644, 69

13. Heusel JW, Siggard-Andersen O, Scott MG: Physiology and disorders of water, electrolyte, and acid-base metabolism. IN Brutis CA, Ashwood ER, Border BG, editors: Tietz fundamentals of clinical chemistry. Saunders; 5 edition (January 15, 2001): 723-46

14. Endres DB, Rude RK: Mineral and bone metabolism. IN Brutis CA, Ashwood ER, Border BG, editors: Tietz fundamentals of clinical chemistry. Saunders; 5 edition (January 15, 2001): 795-821

15. McDermitt DF, Regan MM, Clark JI, Flaherty LE, Weiss $\mathrm{GR}$, et al. Randomized phase III trial of high-dose interleukin-2 versus subcutaneous interleukin-2 and interferon in patients with metastatic renal cell carcinoma. Journal of Clinical Oncology. 2005;23(1)

16. Motzer RJ, Hutson TE, Tomczak P, Michaelson MD, Bukowski RM, et al. Sunitinib versus Interferon Alfa in Metastatic Renal-Cell Carcinoma. The New England Journal of Medicine 2007;356(2)

\section{CLEC Abstract Deadline}

The deadline for abstracts for oral presentation at the 2011 ASCLS Clinical Laboratory Educators' Conference (CLEC) is October 1, 2010. Submission instructions and the proposal form may be found at www.ascls.org/conferences. The completed proposal form and abstract must be submitted electronically by the deadline. There will be no poster presentations or technology demonstrations at CLEC 2011. Presentations acceptable for submission include research studies, teaching tools or education/curriculum projects.

The 2011 CLEC will be held February 17-21 in Fort Lauderdale, FL. Additional meeting information will be available at the ASCLS Conferences website. 